\title{
Guidelines for the Perplexed: How to Maximize Colonoscopy Efficiency During the COVID-19 Pandemic
}

\author{
Enzo Grossi ${ }^{1} \cdot$ Fabio Pace $^{2}$
}

Accepted: 21 September 2020 / Published online: 1 October 2020

(c) Springer Science+Business Media, LLC, part of Springer Nature 2020

The recent SARS-CoV-2 pandemic behaved like a tsunami for many healthcare systems worldwide, as for example in the USA, India and Europe. Restricting the observation angle to the field of gastroenterology, a great number of new relevant clinical data have been produced in an exceedingly short period of time, such as the observation that the disease, originally considered as a respiratory illness, commonly features a variety of gastrointestinal intestinal symptoms and that the digestive system appears to be involved in disease pathogenesis [1-3]. From the organizational site, endoscopy suites have been forced to suspend non-urgent procedures in order to re-allocate human resources to the care of COVID19 positive inpatients during the early phase of pandemic [4-6] and are now planning how to gradually return to preCOVID routine endoscopy activity [7]. The consequences of delaying the return to routine endoscopy are seriously impacting the health system; in the USA alone, a hypothetical suspension of elective endoscopy for 6 months is predicted to delay the diagnosis of over 2800 colorectal cancers and 22,000 adenomatous polyps with malignant potential [8]. The 6-month mortality rate for those eventually diagnosed with colorectal cancer is predicted to increase by $6.5 \%$ [9]. Nevertheless, the problem of re-starting nonurgent procedures while the COVID pandemic is ongoing with the need of maintaining protective measures and social distancing is present, the volume of procedures is going to overwhelm existing resources, resulting in a backlog of procedures. Thus, as Xiao et al. [10] propose in this issue of Digestive Diseases and Sciences, the policy of appropriately triaging and rescheduling endoscopic procedures, in particular screening and surveillance colonoscopy, should be based on specific and timely adopted new guidelines. Here

Fabio Pace

fabio.pace@unimi.it

Villa Santa Maria Foundation, Tavernerio, Italy

2 Division of Gastroenterology, ASST Bergamo Est, Seriate, BG, Italy probably lies one of the most important problems: which national or international guidelines should be adopted for the purpose? Recommendations have been changing rapidly and need to be updated, mainly due to the new development of worldwide sustained community transmission of COVID19 [11]; moreover, at least 21 specific recommendations are available for endoscopy during the COVID-19 pandemic elaborated by a pool of 93 international and national societies as identified in a recent review [12].

Xiao et al. adopted pre-COVID era guidelines, namely those of the US Multi-Society Task Force (USMSTF) published in 2017 [13] and updated in 2020 [14] as a guide to expanding access to endoscopy. In their single-center observational study of patients scheduled for open-access (OA) colonoscopy ordered by a primary physician over a six-week period during the COVID-19 pandemic, they found that up to one-fifth of colonoscopies can be rescheduled into a future year based on USMTSTF guidelines [14]. Interestingly enough, roughly $75 \%$ of these inappropriately scheduled colonoscopies were non-adherent to the above guidelines, whereas the remaining $25 \%$ was due to inappropriate use of family history by the primary care physician (PCP). Thus, the study confirms that: a) PCPs recommend repeat colonoscopy sooner than guidelines suggest $[15,16]$; and b) a significant proportion of open access colonoscopies for colorectal cancer prevention are indeed inappropriate, confirming the figure of nearly $8 \%$ according to a recent review by Kapila et al. [17]. Thus, the question arises of how to improve the use of OA colonoscopy for CRC screening and surveillance, since this might reduce the volume of procedures without delaying CRC detection. Xiao et al. suggest that this can be accomplished by incorporating guidelines at two points of care, namely following the index colonoscopy and in the PCP's office. Nonetheless, as authors admit, often the PCP simply follows inappropriate recommendations provided by the endoscopist, suggesting lack of awareness or disagreement with existing guidelines. Indeed, predictors for poor adherence to guidelines have been carefully examined and 
suggested [18]. This pushes back to the general issue of how can effective guidelines be proposed and updated, with the conclusion that continuing education is mandatory, in particular in these times of rapidly changing clinical paradigms.

\section{References}

1. Pan L, Mu M, Yang P, et al. Clinical characteristics of COVID19 patients with digestive symptoms in Hubei, China: a descriptive, cross-sectional multicenter study. Am J Gastroenterol. 2020;115:766-773.

2. Han C, Duan C, Zhang S, et al. Digestive symptoms in COVID19 patients with mild disease severity: clinical presentation, stool viral RNA testing, and outcomes. Am J Gastroenterol. 2020;115:916-923.

3. Mao R, Qiu Y, He JS, et al. Manifestations and prognosis of gastrointestinal and liver involvement in patients with COVID-19: a systematic review and meta-analysis. Lancet Gastroenterol Hepatol. 2020;5:667-678.

4. Chiu PWY, Ng SC, Inoue H, et al. Practice of endoscopy during COVID-19 pandemic: position statements of the Asian Pacific Society for Digestive Endoscopy (APSDE-COVID statements). Gut. 2020;69:991-996.

5. The British Society of Gastroenterology. Endoscopy activity and COVID-19: BSG and JAG guidance. London: BSG; 2020.

6. American College of Gastroenterology. Gastroenterology Professional Society Guidance on Endoscopic Procedures during the COVID-19 Pandemic 2020 [cited 13/04/2020]. Available from: https://gi.org/2020/04/01/joint-gi-society-message-on-endoscopyduring-covid-19.

7. Gupta S, Shahidi N, Gilroy N, et al. A proposal for the return to routine endoscopy during the COVID-19 pandemic. Gastrointest Endosc. 2020;92:735-742.

8. Peery AF, Crockett SD, Murphy CC, et al. Burden and cost of gastrointestinal, liver, and pancreatic diseases in the United States: update 2018. Gastroenterology. 2019;156:e11.

9. Pita-Fernández S, González-Sáez L, López-Calviño B, et al. Effect of diagnostic delay on survival in patients with colorectal cancer: a retrospective cohort study. BMC Cancer. 2016;16:664.
10. Xiao AH, Chang SY, Stevolff C, et al. Adoption of multi-society guidelines facilitates value-based reduction in screening and surveillance colonoscopy volume during COVID-19 pandemic. Dig Dis Sci. 2020. (Epub ahead of print). https://doi.org/10.1007/ s10620-020-06539-1.

11. European Centre for Disease Prevention and Control. Novel Coronavirus Disease 2019 (COVID-19) pandemic. Geographic Distribution of COVID-19 Cases Worldwide. Available at: https://www. ecdc.europa.eu/en/ Accessed August 24, 2020.

12. Castro Filho EC, Castro R, Fernandes FF, Pereira G, Perazzo H. Gastrointestinal endoscopy during the COVID-19 pandemic: an updated review of guidelines and statements from international and national societies. Gastrointest Endosc. 2020;92:e6.

13. Rex DK, Boland CR, Dominitz JA, et al. Colorectal cancer screening: recommendations for physicians and patients from the U.S. multi-society task force on colorectal cancer. Gastroenterology. 2017;153:307-323.

14. Gupta S, Lieberman D, Anderson JC, et al. Recommendations for follow-up after colonoscopy and polypectomy: a consensus update by the US multi-society task force on colorectal cancer. Gastroenterology. 2020;158:e1135.

15. Boolchand V, Olds G, Singh J, Singh P, Chak A, Cooper GS. Colorectal screening after polypectomy: a national survey study of primary care physicians. Ann Intern Med. 2006;145:654-659.

16. Johnson MR, Grubber J, Grambow SC, et al. Physician non-adherence to colonoscopy interval guidelines in the veterans affairs healthcare system. Gastroenterology. 2015;149:938-951.

17. Kapila N, Singh H, Kandragunta K, Castro JF. Open access colonoscopy for colorectal cancer prevention: an evaluation of appropriateness and quality. Dig Dis Sci. 2019;64:2798-2805.

18. Iskandar H, Yan Y, Elwing J, Early D, Colditz GA, Wang JS. Predictors of poor adherence of US gastroenterologists with colonoscopy screening and surveillance guidelines. Dig Dis Sci. 2015;60:971-978.https://doi.org/10.1007/s10620-014-3403-0

Publisher's Note Springer Nature remains neutral with regard to jurisdictional claims in published maps and institutional affiliations. 